GOSPODARKA SUROWCAMI MINERALNYMI - MINERAL RESOURCES MANAGEMENT

201

Volume 32

Issue 1

Pages $55-70$

DOI 10.1515/gospo-2016-0001

\title{
The studies of granitoids from the Sobótka region in light of theories of the origin of colour in minerals
}

\section{Introduction}

Colour is one of the most striking and distinctive features of minerals. The physical interpretation of its origin is a very complex issue that requires the use of the solid body electron structure theories, i.e.: crystal field, molecular orbital, and band one as well as of physical optics, to explain the role of intrinsic chemical constituents, impurities, defects, and specific structures in the process leading to the creation of visual effects designated as colour (Table 1; Nassau 1978; Bolewski et al. 1981).

The relationship between the cause of colour and physical theories, provided in Table 1 goes beyond the traditional classification of minerals into four groups: achromatic (colourless), idiochromatic (self-coloured, as from a major ingredient), allochromatic (other-coloured, as from an impurity), and pseudochromatic (false coloured, as originating from optical effects). The interpretation of colour of idio- and allochromatic minerals is based on crystal field, molecular orbital and band theories. The self colour of minerals is primarily due to the selective absorption of light in visible range and in neighbouring ultraviolet and infrared regions, caused by a transition between various electron energy levels (Bolewski et al. 1981). This is frequently connected with the presence of transition metal ions, some REE (lanthanides) and actinides in the crystal lattice, which play the role of chromophores, or with lattice defects. Colour can be attributed to internal electron transition between

* Ph.D. Eng., The Mineral and Energy Economy Research Institute of the Polish Academy of Sciences, Krakow, Poland; e-mail: lewicka@min-pan.krakow.pl 
Table 1. Causes of colour in minerals in light of physical theories (Nassau 1978)

Tabela 1. Przyczyny zabarwienia minerałów w świetle teorii fizyki (Nassau 1978)

\begin{tabular}{|l|l|l|}
\hline \multicolumn{1}{|c|}{ Causes of colour } & \multicolumn{1}{|c|}{ Typical examples } & \multicolumn{1}{c|}{ Theory } \\
\hline $\begin{array}{l}\text { Transition metal compounds } \\
\text { (being the main chemical components) }\end{array}$ & almandite, malachite, turquoise & crystal field theory \\
\hline Transition metal impurities & citrine, emerald, ruby & crystal field theory \\
\hline Colour centres & amethyst, fluorite, smoky quartz & crystal field theory \\
\hline Charge transfer & blue sapphire, crocoite, lazurite & molecular orbital theory \\
\hline Organic materials & amber, coral, graphite & molecular orbital theory \\
\hline Conductors & copper, iron, silver & band theory \\
\hline Semiconductors & galena, proustite, pyrite, sulphur & band theory \\
\hline Doped semiconductors & blue and yellow diamond & band theory \\
\hline Dispersion of light & 'fire' in faceted gems & physical optics \\
\hline Scattering of light & $\begin{array}{l}\text { moonstone, 'tiger eye", minerals } \\
\text { showing asterism }\end{array}$ & physical optics \\
\hline Interference of light & iridescent chalcopyrite & physical optics \\
\hline Diffraction of light & opal & physical optics \\
\hline
\end{tabular}

orbitals, e.g.: violet Ti-rich augite (chromophore $\left.\mathrm{Ti}^{3+}\right)$, green uvarovite $\left(\mathrm{Cr}^{3+}\right)$, brown piemontite $\left(\mathrm{Mn}^{3+}\right)$, rose rodonite $\left(\mathrm{Mn}^{2+}\right)$, green epidote $\left(\mathrm{Fe}^{2+}\right)$, green garnierite $\left(\mathrm{Ni}^{2+}\right)$, bluegreen dioptase $\left(\mathrm{Cu}^{2+}\right)$. The colour reason could be also a charge transfer between neighbouring ions in a crystal lattice, e.g.: brown-red biotite, basalt hornblende, and staurolite, as well as blue tint of glaucophane, kyanite, or cordierite.

The occurrence of a specific colour can be explained in multiple ways, e.g. a deep blue hue may be produced by copper (idiochromatic shattuckite), cobalt (allochromatic spinel), by a colour centre (Maxixe type beryl, irradiated by gamma rays, X-rays or neutrons), by a charge transfer between iron and titanium (blue sapphire), by molecular orbital effects (lapis lazuli), by boron acceptors in a band gap (blue diamond, e.g. Hope), and by pseudochromatic light interference (blue regions in opal). Simultaneously, the same element could cause various colours, such as chromium - a ruby red colour and green emerald colour. This is a consequence of different spatial locations of that ion in a crystal lattice and absorption in various ranges of the spectrum.

The article discusses the results of the studies of feldspar-quartz raw materials coming from deposits located in the Sobótka region in light of four distinct physical theories explaining mechanisms for creating of colour of minerals. This is a successive stage of research carried out by the author on reasons for colour variation of samples after firing at $1200^{\circ} \mathrm{C}$. This step encompassed a detailed chemical analysis of the contents of the main and trace elements of all the investigated samples as well as Mössbauer studies. The aim of the investi- 
gations was to establish the contents of transition elements, REE and actinides, to examine the ratio of iron ions in various valence states, as well as to determine the influence of these components on the colour of the samples after firing.

\section{Origin of the colour of minerals in light of physical theories}

\subsection{Crystal field theory}

The crystal field theory best explains the colour origin of ionic crystals, dominating in the world of minerals, which may contain ions of transition elements. These elements can occur as a main component of a mineral or as an impurity. This most frequently refers to the elements with partially filled $d$ shells such as $\mathrm{V}, \mathrm{Cr}, \mathrm{Mn}, \mathrm{Fe}, \mathrm{Ti}, \mathrm{Co}, \mathrm{Ni}, \mathrm{Cu}$, as well as to some REE and actinides, having partially filled $f$ shells. This theory describes an influence of electrostatic field occurring inside crystals on energy levels of transition metals in the crystal structure (Czaja 2002). Unpaired electrons can interact with visible light (they are excited to a higher energy level) that results in absorption and colour appearance. When electrons come back to the basic level ("ground state") some heat can be emitted to the crystal lattice resulting in a light emission of the defined wavelength. The scheme of passing of electrons to particular energy levels accompanied by absorption or emission of light is a typical feature of each mineral. When all electron shells of ion/atom are completely full or empty as in $\mathrm{Cr}^{6+}, \mathrm{Ce}^{4+}$, or $\mathrm{Cu}^{+}$(there are no unpaired electrons) - colour doesn't appear. Among the transition metals, iron is the most plentiful (around 5\% of the earth's crust) and is therefore the dominant colour contributor in minerals.

Idiochromatic minerals being the compounds of transition metals, some REE and actinides are the following: yellow parisite (Ce compound); orange crocoite and green uvarovite (Cr compounds); pink: erythrite and roselite (Co compounds); blue: azurite, chrysocolla and turquoise, green: dioptase and malachite, red cuprite ( $\mathrm{Cu}$ compounds); blue lapis lazuli, green olivine, red: almandine and ludlockite, yellow: goethite and cacoxenite (Fe compounds); pink: rhodochrosite and rhodonite, orange spessartine, brown ganophyllite (Mn compounds); green bunsenite ( $\mathrm{Ni}$ compound); yellow: autunite and carnotite, orange-red curite (U compounds). Furthermore, colour can be caused by impurities of transition metal ions. For example, $\mathrm{Cr}$ ions result in colouring of green: emerald, grossularite, hiddenite, $\mathrm{Cr}$-rich jade, Cr-rich tourmaline, green-red alexandrite, and red: ruby and topaz; $\mathrm{Fe}$ - green: aquamarine, tourmaline, yellow: chrysoberyl, citrine, vesuvianite, orthoclase, green amethyst, green-yellow-brown jade; Mn - pink: morganite, spodumene, tourmaline, green and yellow andalusite; $\mathrm{Ni}$ - green chrysoprase; $\mathrm{V}$ - green: apophyllite, tsavorite, V-rich grossularite and V-rich emerald. In addition, depending on the strength of the crystal field of a mineral some of the above-mentioned cations exhibit luminescence, e.g. $\mathrm{Cr}^{3+}, \mathrm{V}^{3+}, \mathrm{Mn}^{2+}$ (Czaja 2002). 
The emergence of colour as a result of light absorption by an unpaired electron can also be the case - under certain circumstances - when an electron is located on a non-transition element ion or on a crystal defect such as a missing ion (vacancy). Both of them can be the cause of colour centre. If an electron is present at a vacancy - this is an 'electron' colour centre; if an electron is missing from a location where an electron pair usually occurs - this is a 'hole' colour centre. Widely known examples of minerals, the colouring of which is a result of colour centres of these kinds are respectively: fluorite (purple ' $F$ centre' called Frenkel defect where an electron occupies the empty position after missing anion $\mathrm{F}^{-}$) and smoky quartz ('V hole centre'). The crystal lattice of the latter contains some $\mathrm{Al}^{3+}$ substituting for $\mathrm{Si}^{4+}$, with alkali cations nearby $\left(\mathrm{Na}^{+}, \mathrm{Li}^{+}\right.$or $\left.\mathrm{H}^{+}\right)$, compensating the charge. Most natural quartz contains substitutional $\mathrm{Al}$ at the several hundred ppm level, but this does not produce colour. However, if such crystal quartz is irradiated with X-rays, gamma rays, neutrons etc., or if it was exposed to a low level of such radiation over geologic time period, then one electron from a pair located on an oxygen adjacent to $\mathrm{Al}$ can be ejected from its position, leaving unpaired electrons. Thus, light absorbing transitions are possible, resulting in the smoky colour of quartz. The displaced electron can be trapped somewhere else in the crystal without any additional light absorption. If the smoky quartz is heated to e.g. $400^{\circ} \mathrm{C}$, these displaced electrons can return to the hole centre; all electrons are paired and the crystal once again becomes colourless (Nassau 1978). Re-irradiation results in grey colour restoration. Another example of the 'hole' colour centre presence is amethyst, involving substitution $\mathrm{Fe}$ instead of Al. Depending on the location of Fe ions and their environment in the lattice, the crystal colour obtained on heating is either yellow (citrine) or green (green amethyst from Montezuma). Re-irradiation can reproduce a colour centre and restore a colour related to this centre. It is worth mentioning that even UV radiation (of low energy) can produce a colour centre. Some of these colours are not stable to light exposure, e.g. deep blue Maxixe type beryl, irradiated brown topaz, yellow sapphire, purple hackmanite (when kept in the dark, the colour of these minerals will persist over many years, e.g. in the case of Maxixe beryl - more than 60; Nassau 1978). The test for a colour centre is bleaching by light or heat and reformation of the colour after irradiation.

\subsection{Molecular orbital theory}

This theory involves electrons which are not located on single atoms or ions - as in the crystal field theory - but are considered to be present in orbits common for a molecule as a whole (Bolewski et al. 1981). Depending on the type of central atoms of the molecule (metal-metal, metal-nonmetal or nonmetal-nonmetal) the set of energy levels and associated electron transition probabilities are created.

An example of charge transfer between metals is sapphire $\left(\mathrm{Al}_{2} \mathrm{O}_{3}\right)$ with impurities of both $\mathrm{Ti}$ and $\mathrm{Fe}$ ions, which can exist in two valence states: $\mathrm{Fe}^{2+}$ and $\mathrm{Ti}^{4+}$ or $\mathrm{Fe}^{3+}$ and $\mathrm{Ti}^{3+}$. A single electron can be transferred by light absorption from $\mathrm{Fe}$ to Ti, i.e. 
$\mathrm{Fe}^{2+}-\mathrm{Ti}^{4+} \rightarrow \mathrm{Fe}^{3+}-\mathrm{Ti}^{3+}$. This produces a broad intense absorption band at the red end of the spectrum, resulting in a deep blue colour. Another example is vivianite (hydrated iron phosphate), the colour of which depends solely on the valence state of iron. Fresh crystals of that mineral contain only $\mathrm{Fe}^{2+}$ and are almost colourless. Air-oxidation converts some of the $\mathrm{Fe}^{2+}$ to $\mathrm{Fe}^{3+}$ and a deep blue colour appears, following a charge transfer. In turn, the black colour of mineral manganite can be a result of a charge transfer between Mn ions, i.e. $\mathrm{Mn}^{2+}-\mathrm{Mn}^{4+} \rightarrow \mathrm{Mn}^{3+}-\mathrm{Mn}^{3+}$.

The charge transfer between metals and non-metals can be exemplified by crocoite $\left(\mathrm{PbCrO}_{4}\right)$. Ions of $\mathrm{Pb}^{2+}, \mathrm{Cr}^{6+}$ and $\mathrm{O}^{2-}$ present in its structure do not have any unpaired electrons as their electron shells are completely filled in. However, there are molecular units $\mathrm{CrO}_{4}{ }^{2-}$ which are covalently bonded, while the bonding electrons are located on molecular orbitals belonging to the unit as a whole. In these circumstances a charge transfer between oxygen anion and central cation $\left(\mathrm{Cr}^{6+}\right)$ is possible. This is accompanied by a broad absorption at the blue end of the spectrum and the transmittance of the other wavelengths. The result is the orange colour of the crystal. Similar remarks also apply to orange vanadinite, the colour of which is caused by a charge transfer between $\mathrm{V}^{5+}$ and $\mathrm{O}^{2-}$.

The molecular orbitals theory also explains the colouring of numerous minerals, in which metal ions are not involved. An example is deep blue lapis lazuli (lazurite) including $\mathrm{S}_{3}{ }^{-}$molecular units and no unpaired electrons on the atom shells. The charge transfer takes place within covalently bonded molecular units. There are a number of mineral substances which owe their colour to organic pigments, e.g.: amber, ivory, coral, pearl, bitumen, lignite, etc. (Nassau 1978).

\subsection{Band theory}

This theory, to a certain extent linked to the crystal field theory, describes the behaviour of electrons in crystalline solid bodies. It explains e.g. causes of colouring of many sulphide and oxide minerals (which do not contain transition elements), as well as native metals, e.g. copper, gold, iron, silver, mercury.

Energy bands are created in the crystal structure of minerals, due to interactions of atoms arranging the crystal lattice. Bands where electrons can move are called permitted. They are separated by prohibited space (band gap), but sometimes overlap (in the case of metals). The highest band filled with electrons is called the valence band (basic), while an adjacent empty band, to which electrons can pass from valence band after getting relevant energy, is defined as the conduction band. In that perspective, the colour of a mineral is a result of the passing of electrons from the valence band to the conduction one (Bolewski et al. 1981).

In the case of insulators, the energy required for transferring an electron from valence band to the conduction band is $5-10 \mathrm{eV}$ and can be provided by the application of very high voltage or heating. The band-gap energy of semiconductors ranges from 1 to $2 \mathrm{eV}$. If the energy needed to pass an electron to the conduction band is less than $1.8 \mathrm{eV}$, all the visible- 
-light range can be absorbed and a dark grey or black colour results, e.g.: galena $(<0.4 \mathrm{eV})$, antimonite $(1.7 \mathrm{eV})$, metacinnabar $(0.6 \mathrm{eV})$ etc. After heating to a high temperature, a mineral of this type can behave as a metal. On the other hand - if the width of band gap is larger than the range of visible light, no photon is able to excite an electron to bridge the gap, the light is not absorbed and the mineral is colourless, e.g.: diamond $(5.33 \mathrm{eV})$, sphalerite, and zincite. With a band-gap energy of about $2.5 \mathrm{eV}$, only components of the spectrum of the highest energy (blue and violet) are absorbed and the resulting colour of the mineral is yellow or orange, e.g.: a lemon-yellow orpiment $(2.5 \mathrm{eV})$, orange-yellow greenockite $(2.4 \mathrm{eV})$, red -orange realgar $(2.3 \mathrm{eV})$, as well as red pyrargyrite.

A substantial change of the semiconductor's absorption capacity can be caused by some specific impurities. An example is nitrogen, the atoms of which can substitute for carbon in the crystal lattice of a diamond. Since a nitrogen atom has one more electron than carbon, each nitrogen atom donates one extra electron below the conduction band and these donor electrons form an impurity level within the band gap (Nassau 1978). In such a case, an intense yellow colour of diamond can appear with little energetic effort, i.e. the absorption of a small dose of energy (ca. $3 \mathrm{eV}$ ) from ultraviolet range. Such an effect can be caused by only one nitrogen atom for every 100,000 carbon atoms. In turn, an impurity of boron, having one electron less than carbon, can act in a similar way to create an 'acceptor level' in the band gap. That new level can accept electrons from the valence band of carbon, resulting in the absorption of light and the blue colour of a diamond. This was confirmed by a laboratory synthesis, which showed that even one boron atom per million carbon atoms can be the blue colour contributor in a diamond (Nassau 1978).

\subsection{Physical optics}

The nature of the forming of the pseudochromatic colour of some minerals can be explained by the phenomena of physical optics, i.e.: dispersion, scattering, interference, and dispersion of the light on the surface or the inside of crystals. Depending on the optical effects, the following are distinguished: aventurescence, iridescence, and opalescence.

Aventurescence is a play of colours caused by a reflection and scattering of light on platy mineral inclusions (of mica, ilmenite, or hematite) in the basic mineral that gives a shimmering or glistening effect. Depending on the inclusion, the reflection colours can be green, yellow, gold, orange, or red, less frequently - blue. For example - flakes of fuchsite (Cr-rich muscovite) in aventurine (variety of quartz) result in a green hue, while hematite flakes in aventurine feldspar (sunstone) - copper-red shade.

Iridescence (rainbow effect) is a colourful flickering, being a result of the interference of light reflected from surfaces of bonding or subtle cleavage plates. This phenomenon is characteristic for plagioclases, especially for labrador. Iridescence can occur on the surface of opaque minerals of metallic gloss. It is caused by thin tarnish film of products of oxidation. Interference of light in a thin film can be also observed on the surface of weathered bornite, 
chalcopyrite, or covellite - colour sequence depends on the film thickness, the refractive index of the film, and the nature of the incident light. Adularescence is a particular variety of opalescence. This is a silver-milky or silver-bluish luster on the surface of mineral caused by reflection of short wave blue light and its scattering on micro-cracks and liquid inclusions, observed in adularia (moonstone), sometimes also in orthoclase and sanidyne, exceptionally in microcline.

Opalescence is characteristic play of colour, resulting from diffraction and scattering, and then the interference of light on a regular diffraction grating, built of small spherical particles of hydrated silica, as in precious opal. The scale of colour depends on the grating spacing ( $3 \AA$ - from green to red, $2.5 \AA$ - from blue to yellow, $2 \AA$ - from violet to sapphire) and the angle of observation. Light dispersion is the main reason for 'fire' reflexes in crystals of strontium titanate, diamond, zircon, and ruby, especially after their polishing.

\section{Results of the research of granitoids from the Sobótka region}

\subsection{Introduction}

The subject of the research was 19 samples of feldspar-quartz raw materials from deposits operated by the Strzeblowskie Kopalnie Surowców Mineralnych (SKSM) of Sobótka, i.e.: Pagórki Zachodnie (PZ), Pagórki Wschodnie (PW), Stary Łom (SL), and Strzeblów I (SI). These materials were formed into pellets and then fired at $1200^{\circ} \mathrm{C}$ in the SKSM's laboratory furnace. Each sample was investigated for the main and trace chemical components, while two of them were analysed by the Mössbauer spectroscopy method. The work carried out followed up previous investigations of the author, which focused on forms and concentrations of colouring elements and compounds as well reasons for colour differentiation of feldspar samples from the Sobótka region after firing (Lewicka 2013, 2015). In the framework of that research, colour parameters of the samples were determined by the spectrometric method acc. to the CIE L*a*b* model (Lewicka 2013). In the model, ' $L$ ' refers to the brightness of the sample, ' $a$ ' - to red $(a>0)$ or green $(a<0)$ colour, and 'b' - to yellow $(b>0)$ or blue $(b<0)$ colour (Mielicki 1997). The measurements results are presented in Table 2, while a visualisation of colours made on the basis of values $\mathrm{L}^{*} \mathrm{a}^{*} \mathrm{~b}^{*}$ is shown in Figure 1. This enabled the assessment and comparison of the samples' colours.

\subsection{Results of full chemical analysis}

Chemical analyses for the main and trace elements were performed by Activation Laboratories - ACTLABS in Ancaster (Ontario, Canada), using FUS-ICP - fusion - inductively 
Table 2. L*a*b* colour parameters of raw material samples from SKSM's deposits

Tabela 2. Parametry L*a*b* barwy próbek kopaliny ze złóż SKSM

\begin{tabular}{|c|c|c|c|}
\hline Sample & L*[\%] & $\mathrm{a}^{*}$ & $\mathrm{~b}^{*}$ \\
\hline PZ-1 & 58.68 & 8.86 & 7.32 \\
\hline PZ-2 & 69.98 & 5.86 & 9.27 \\
\hline PZ-3 & 82.64 & 0.68 & 9.60 \\
\hline PZ-4 & 61.37 & 6.05 & 5.59 \\
\hline PW-1 & 75.39 & 1.53 & 6.76 \\
\hline PW-2 & 57.67 & 3.52 & 3.20 \\
\hline PW-3 & 73.91 & 2.88 & 5.66 \\
\hline PW-4 & 83.26 & 1.50 & 6.35 \\
\hline SL-1 & 74.31 & 2.03 & 7.04 \\
\hline SL-2 & 66.96 & 1.22 & 1.83 \\
\hline SI-1 & 78.44 & 0.11 & 6.24 \\
\hline SI-2 & 75.93 & 2.90 & 7.70 \\
\hline SI-3 & 74.49 & 1.91 & 7.26 \\
\hline SI-4 & 70.99 & 2.92 & 6.03 \\
\hline SI-5 & 53.08 & 3.89 & 2.49 \\
\hline SI-6 & 52.79 & 4.92 & 4.07 \\
\hline SI-7 & 78.50 & 2.06 & 8.85 \\
\hline SI-8 & 75.23 & 3.88 & 9.10 \\
\hline SI-9 & 81.73 & 0.62 & 6.37 \\
\hline
\end{tabular}

$\mathrm{PZ}-1$

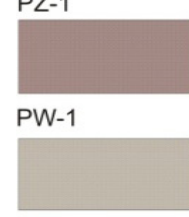

SL-1

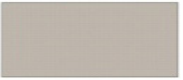

SI-1

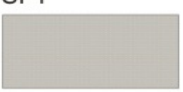

SI-5

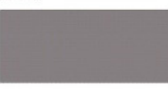

SI-9
PZ-3

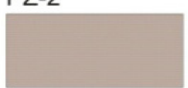

PW-2

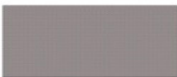

SL-2

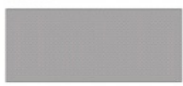

$\mathrm{SI}-2$

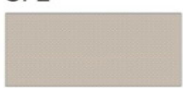

SI-6

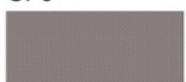

PW-3

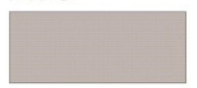

SI-3

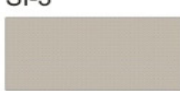

SI-7

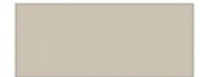

PZ-4

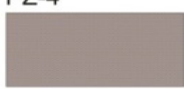

PW-4

SI-4

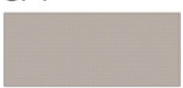

SI-8

Fig. 1. Colour of samples from respective deposits of SKSM acc. to $L * a * b *$ palette

Rys. 1. Barwa próbek z poszczególnych złóż SKSM według palety L*a*b* 
coupled plasma and TD-ICP - total digestion - inductively coupled plasma methods as well as INAA - instrumental neutron activation analysis.

There were 13 samples examined (the remaining six samples were analysed in the previous stage of the research). The results of the full chemical analysis revealed the presence and value share of colouring compounds and elements, i.e.: $\mathrm{Fe}_{2} \mathrm{O}_{3}, \mathrm{TiO}_{2}, \mathrm{MnO}$, $\mathrm{Cu}, \mathrm{Ni}, \mathrm{Th}, \mathrm{U}, \mathrm{V}, \mathrm{Ce}$, and $\mathrm{Nd}$ (Table 3). Other colouring elements such as $\mathrm{Cr}$ and Co were not detected; their contents were well below the detection limits of analytical methods applied.

Table 3. Contents of colouring components and elements in raw material samples from:

Pagórki Zachodnie (PZ), Pagórki Wschodnie (PW), Stary Łom (SL), Strzeblów I (SI) deposits

Tabela 3. Zawartość składników i pierwiastków barwiących w próbkach kopaliny ze złóż:

Pagórki Zachodnie (PZ), Pagórki Wschodnie (PW), Stary Łom (SL), Strzeblów I (SI)

\begin{tabular}{|c|c|c|c|c|c|c|c|c|c|c|}
\hline Sample & $\begin{array}{c}\mathrm{Fe}_{2} \mathrm{O}_{3} \\
{[\%]}\end{array}$ & $\begin{array}{c}\mathrm{TiO}_{2} \\
{[\%]}\end{array}$ & $\begin{array}{c}\mathrm{MnO} \\
{[\%]}\end{array}$ & $\begin{array}{c}\mathrm{Cu} \\
{[\mathrm{ppm}]}\end{array}$ & $\begin{array}{c}\mathrm{Ni} \\
{[\mathrm{ppm}]}\end{array}$ & $\begin{array}{c}\mathrm{Th} \\
{[\mathrm{ppm}]}\end{array}$ & $\begin{array}{c}\mathrm{U} \\
{[\mathrm{ppm}]}\end{array}$ & $\begin{array}{c}\mathrm{V} \\
{[\mathrm{ppm}]}\end{array}$ & $\begin{array}{c}\mathrm{Ce} \\
{[\mathrm{ppm}]}\end{array}$ & $\begin{array}{c}\mathrm{Nd} \\
{[\mathrm{ppm}]}\end{array}$ \\
\hline PZ-1 & 0.43 & 0.052 & $<0.01$ & 9 & $<1$ & 12.2 & 5.6 & $<5$ & 25 & 12 \\
\hline PZ-2 & 0.33 & 0.073 & $<0.01$ & 3 & $<1$ & 12.8 & 1.8 & 10 & 40 & 24 \\
\hline PZ-3 & 0.19 & 0.095 & $<0.01$ & 6 & $<1$ & 12.9 & 2.5 & 5 & 22 & 9 \\
\hline PZ-4 & 0.34 & 0.048 & $<0.01$ & 3 & $<1$ & 20.2 & 5.1 & $<5$ & 33 & 10 \\
\hline PW-1 & 0.30 & 0.027 & 0.02 & 3 & 1 & 15.3 & 2.4 & 7 & 27 & $<5$ \\
\hline PW-2 & 0.65 & 0.021 & 0.11 & 1 & $<1$ & 9.4 & 16.2 & $<5$ & 19 & 10 \\
\hline PW-3 & 0.34 & 0.019 & 0.03 & 2 & 2 & 9.5 & 0.9 & 5 & 21 & 10 \\
\hline PW-4 & 0.22 & 0.020 & $<0.01$ & 3 & $<1$ & 13.6 & 1.7 & 9 & 21 & 9 \\
\hline SL-1 & 0.26 & 0.022 & 0.02 & 2 & $<1$ & 11.0 & 2.9 & $<5$ & 28 & 7 \\
\hline SL-2 & 0.28 & 0.019 & 0.03 & 3 & 1 & 17.5 & 2.6 & $<5$ & 40 & 24 \\
\hline SI-1 & 0.17 & 0.053 & $<0.01$ & 2 & 3 & 14.9 & 1.1 & $<5$ & 32 & 13 \\
\hline SI-2 & 0.25 & 0.060 & $<0.01$ & 4 & $<1$ & 12.6 & $<0.5$ & 6 & 24 & 10 \\
\hline SI-3 & 0.22 & 0.048 & $<0.01$ & 1 & 5 & 18.7 & 2.7 & $<5$ & 30 & 11 \\
\hline SI-4 & 0.31 & 0.050 & $<0.01$ & 15 & $<1$ & 22.3 & 2.3 & 6 & 29 & 14 \\
\hline SI-5 & 0.66 & 0.054 & $<0.01$ & 2 & 2 & 19.1 & 3.5 & $<5$ & 23 & 10 \\
\hline SI-6 & 0.60 & 0.056 & 0.01 & 6 & 3 & 14.7 & 7.5 & $<5$ & 18 & 5 \\
\hline SI-7 & 0.23 & 0.049 & $<0.01$ & 2 & 2 & 14.3 & 2.6 & $<5$ & 25 & 8 \\
\hline SI- 8 & 0.31 & 0.065 & $<0.01$ & 2 & 2 & 21.5 & 4.9 & 9 & 29 & 18 \\
\hline SI-9 & 0.15 & 0.032 & $<0.01$ & 2 & $<1$ & 9.9 & 2.4 & $<5$ & 24 & $<5$ \\
\hline Detection limit & 0.01 & 0.005 & 0.01 & 1 & 1 & 0.5 & 0.5 & 5 & 3 & 5 \\
\hline
\end{tabular}


Analysing the achieved results in the context of the visualisation shown in Figure 1, it should be noted that:

- the darkest colours reveal the samples characterized by the highest contents of $\mathrm{Fe}_{2} \mathrm{O}_{3}$, i.e.: PW-2 (also showing the highest content of $\mathrm{MnO}$ and $\mathrm{U}$, and low content of $\mathrm{TiO}_{2}$ ) as well as SI-5 and SI-6, also with a relatively high share of Th,

- opaque red-brown colour of samples PZ-1 and PZ-4, and to some extent also PZ-2 and SI-8, can be attributed to the share of $\mathrm{Fe}_{2} \mathrm{O}_{3}, \mathrm{U}, \mathrm{Ce}, \mathrm{Nd}$, and V (especially PZ-2),

- samples of the lightest hues have the lowest contents of $\mathrm{Fe}_{2} \mathrm{O}_{3}$, accompanied by a relatively low share of $\mathrm{U}$ and $\mathrm{MnO}$ (usually below the detection limit),

- grey shade of the samples with a relatively low contents of $\mathrm{Fe}_{2} \mathrm{O}_{3}$, such as SL-1, SL-2, or PW-3, can be related to fairly high shares of $\mathrm{MnO}$ and $\mathrm{Th}$.

\subsection{Mössbauer studies}

As previously mentioned, the colour of minerals is very much influenced by the valence states of cations occurring in their structure. Of the transition elements, $\mathrm{Fe}$, is the dominant colour contributor in minerals. Two samples that distinctly differ in respect to $\mathrm{Fe}_{2} \mathrm{O}_{3}$ contents and colour after firing, i.e.: PW-2 and PZ-2, were examined by the Mössbauer spectroscopy method. The purpose of the research was the determination of the $\mathrm{Fe}^{2+}$ to $\mathrm{Fe}^{3+}$ ratio in the samples. The investigations were performed by the Mössbauer Spectroscopy Laboratory of the Pedagogical University in Kraków. The spectra were collected using the RENON MsAa-3 spectrometer. The ${ }^{57} \mathrm{Co}(\mathrm{Rh})$ isotope was used as a source of radiation. Transmission geometry with the source and absorbers kept at room temperature was applied. All spectra shifts were reported versus the total shift in $\alpha$-Fe.

Mössbauer studies revealed a significant (more than two-fold) prevalence of the relative content of $\mathrm{Fe}^{2+}\left(69 \%\right.$, i.e. absolute content of $0.31 \%$ in the sample) over $\mathrm{Fe}^{3+}(31 \%$, i.e. absolute content of $0.14 \%)$ in the sample PW-2, belonging to the richest in $\mathrm{Fe}_{2} \mathrm{O}_{3}(0.65 \%$, Table 3) and the darkest among the investigated materials, as it was indicated by the ' $\mathrm{L}$ ' value (Table 2). Its spectrum exhibited two non-magnetic/paramagnetic doublets of absorption lines per each cation (Fig. 2). According to the values of their hyperfine parameters, i.e. isomer shift and quadrupole splitting, these subcomponents probably represent iron ions in chlorite $\left(\mathrm{Fe}^{2+}\right.$, blue line) and mica/biotite or hematite $\left(\mathrm{Fe}^{3+}\right.$, green line) (Table 4, see: Stevens et al. 2005).

In the case of another sample - PZ-2, containing $0.33 \% \mathrm{Fe}_{2} \mathrm{O}_{3}-\mathrm{Fe}^{3+}$ cations dominated (78\%, i.e. absolute content of $0.18 \%$ in the sample), while $\mathrm{Fe}^{2+}$ constituted $22 \%$ (absolute content of $0.05 \%$ ). In the spectrum of this sample, despite significantly scattered experimental points, two non-magnetic/paramagnetic absorption lines belonging to $\mathrm{Fe}^{2+}$ and $\mathrm{Fe}^{3+}$ were distinguished (green and blue line, respectively). These cations are assumed to be located in the structure of chlorite or kaolinite $\left(\mathrm{Fe}^{2+}\right)$ and pyrite or garnet $\left(\mathrm{Fe}^{3+}\right)$, although in this case the quality of the fitting of modelling data to the parameters of the obtained experimental 
Table 4. Parameters of Mössbauer spectra of PW-2 and PZ-2 samples

Tabela 4. Parametry mössbauerowskie widm próbek PW-2 i PZ-2

\begin{tabular}{|c|c|c|c|c|c|}
\hline Sample & Valence state & A [at. \%] & IS [mm/s] & QS [mm/s] & $\Gamma[\mathrm{mm} / \mathrm{s}]$ \\
\hline \multirow{3}{*}{$\mathrm{PW}-2$} & \multirow{2}{*}{$\mathrm{Fe}^{2+}$} & $34(2)$ & $1.44(1)$ & $3.22(1)$ & $0.20(2)$ \\
\cline { 3 - 6 } & & $35(2)$ & $0.99(1)$ & $2.90(3)$ & $0.24(2)$ \\
\cline { 2 - 6 } & \multirow{2}{*}{$\mathrm{Fe}^{3+}$} & $14(5)$ & $0.30(5)$ & $1.4(2)$ & $0.4(1)$ \\
\cline { 2 - 6 } & & $17(5)$ & $0.35(2)$ & $0.5(1)$ & $0.3(1)$ \\
\hline \multirow{2}{*}{$\mathrm{PZ}-2$} & $\mathrm{Fe}^{2+}$ & $22(4)$ & $1.11(4)$ & $2.9(1)$ & $0.4(1)$ \\
\cline { 2 - 6 } & $\mathrm{Fe}^{3+}$ & $78(4)$ & $0.32(2)$ & $0.64(3)$ & $0.55(5)$ \\
\hline
\end{tabular}

A - relative content of iron of respective valence state, IS - isomer (total) shift versus $\alpha-\mathrm{Fe}$, QS - quadrupole splitting, $\mathrm{G}$ - absorber line width
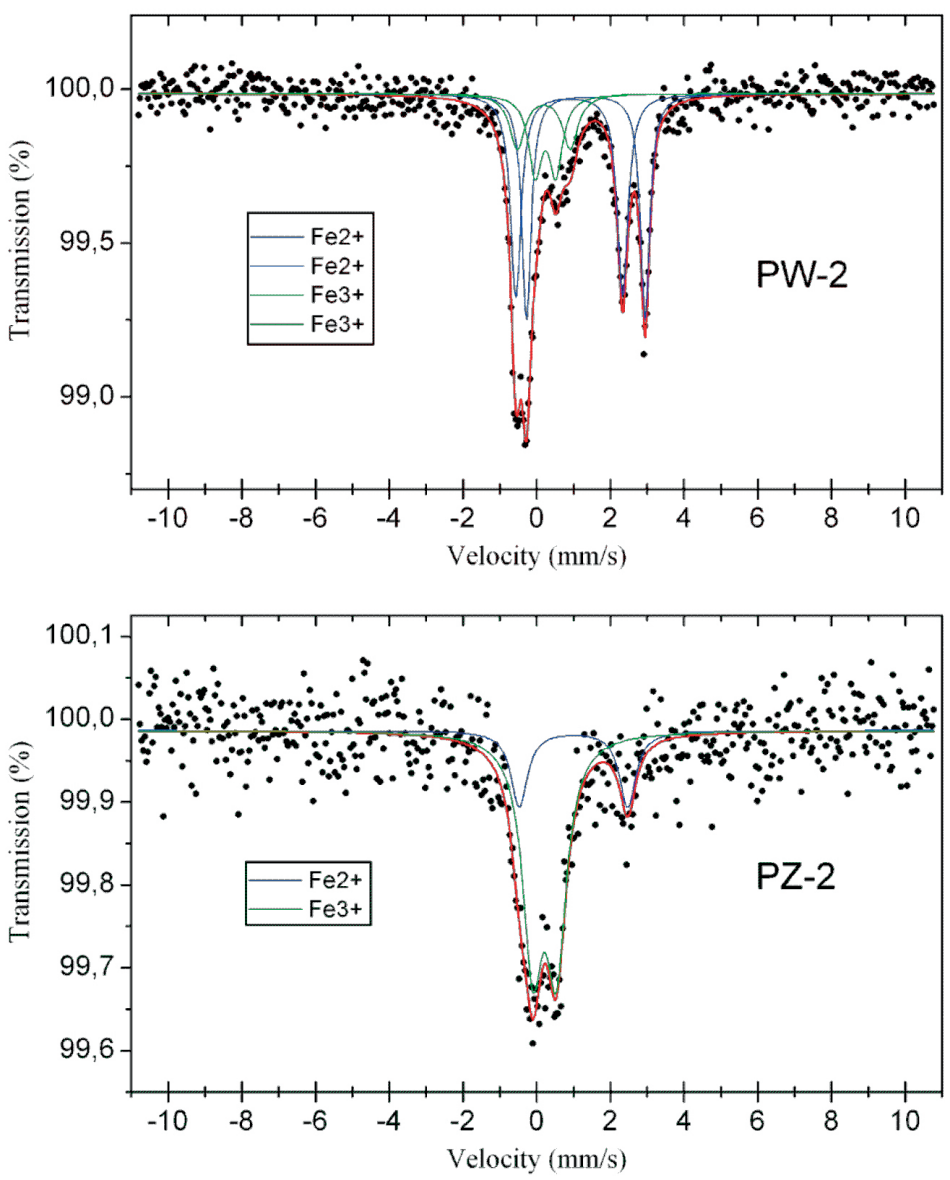

Fig. 2. Experimental Mössbauer spectra of PW-2 and PZ-2 samples (room temperature)

Rys. 2. Eksperymentalne widma mössbauerowskie próbek PW-2 i PZ-2 (pomiar w temperaturze pokojowej) 
spectrum seems to be low (Stevens et al. 2005). The value of isomer shift of $\mathrm{Fe}^{2+}$ in the sample PZ-2 (IS = 1.11) indicates that ferrous ion probably occurs in octahedral coordination set for this ion in crystalline substances (Bancroft 1973). The isomer shift of ferric ions in both samples $(0.30-0.35)$ can refer to tetrahedral coordination in the crystal lattice (Steffen et al. 1984; Spiering and Seifert 1985). The examined samples do not exhibited magnetic behaviours at room temperature.

In light of the foregoing, it can be concluded that the high content of $\mathrm{Fe}^{2+}$ in the sample resulted in a reduction of the values of ' $a$ ' and ' $b$ ' colour parameters, and to a lesser extent - also the ' $\mathrm{L}$ ' value. Moreover, the ratio of $\mathrm{Fe}^{2+}$ to $\mathrm{Fe}^{3+}$ can be influenced by a $\mathrm{TiO}_{2}$ presence. The work conducted on the redox equilibria of $\mathrm{Fe}$ and Ti-bearing silica glass showed that $\mathrm{Ti}^{4+}$ tends to enhance the stability of $\mathrm{Fe}^{3+}$ relative to that of $\mathrm{Fe}^{2+}$ due to the structural instability of the $\mathrm{Fe}^{2+}-\mathrm{O}-\mathrm{Ti}^{4+}$ network (Alberto et al. 1992). It was also found that the following configuration: $\mathrm{Fe}^{2+}-\mathrm{O}-\mathrm{Ti}^{4+}$ favours the transfer of electrons via the oxygen atom, i.e.: $\mathrm{Fe}^{2+}-\mathrm{O}-\mathrm{Ti}^{4+} \rightarrow \mathrm{Fe}^{3+}-\mathrm{O}-\mathrm{Ti}^{3+}$. This phenomenon was termed as the titania effect (Weaver 1976; Chyandrasekhar and Ramaswamy 2002). This seems to coincide with the fact that sample PZ-2, in which ferric ions prevail, contains much more $\mathrm{TiO}_{2}(0.07 \%)$, than sample PW-2 $\left(0.02 \% \mathrm{TiO}_{2}\right)$, which is characterized by the predominance of ferrous ions (Table 3).

\subsection{Discussion of results of the study and conclusions}

At this stage of research, the crystal field theory, which relates certain colour appearance with the presence of transition metals, some REE and actinides in the structure of minerals, as well as their capacity to selectively absorb visible light seems to be the most suitable for the colour formation of the examined samples of granitoids from the Sobótka region. A full chemical analysis of the samples in question showed a significant diversification of these elements contents, especially $\mathrm{Fe}$ and $\mathrm{Ti}$, as well as: $\mathrm{V}, \mathrm{Mn}, \mathrm{Ni}, \mathrm{Cu}, \mathrm{Ce}, \mathrm{Nd}, \mathrm{Th}$, and $\mathrm{U}$. These elements have strong colouring properties and/or the ability to modify colour. Depending on the valence state, iron is responsible for red or red-brown $\left(\mathrm{Fe}^{3+}\right)$ or greenish-blue colour $\left(\mathrm{Fe}^{2+}\right)$, titanium - yellow, manganium compounds - violet, brown or black, cerium impurity - light blue or yellow, neodymium - pink-red, thorium - black, and uranium - black or yellow-red (Bolewski et al. 1991), while vanadium in various oxidation states causes black colour $\left(\mathrm{V}^{2+}\right.$ and $\left.\mathrm{V}^{3+}\right)$, dark blue $\left(\mathrm{V}^{4+}\right)$ or hues varying from orange to dark brown $\left(\mathrm{V}^{5+}\right)$ (Dziubak 2012).

With the exception of the valence state, colour is influenced by ion coordination, i.e. the tetrahedral or octahedral position in the crystal lattice. This issue was best understood for structures containing iron cations. Examinations carried out (vide Sikora 1974) demonstrated that the presence of $\mathrm{Fe}^{3+}$ tetrahedrally coordinated influences the colour of minerals in a much stronger manner than its location in the octahedral coordination. Furthermore, even a very small quantity of $\mathrm{Fe}^{3+}$ in the octahedral position causes an intensive red-brown co- 
louring while its location solely in octahedral position - a green colour. Minerals with $\mathrm{Fe}^{2+}$ octahedrally coordinated have shades in green and blue.

Key information on the valence state of iron as well as $\mathrm{Fe}^{2+} / \mathrm{Fe}^{3+}$ ratio was provided by the Mössbauer studies of two selected samples (PW-2 and PZ-2). Sample PW-2, characterised by one of the highest contents of $\mathrm{Fe}_{2} \mathrm{O}_{3}, \mathrm{MnO}$, and $\mathrm{U}$ among the examined material $\left(0.65 \%, 0.11 \%\right.$ and $16.2 \mathrm{ppm}$, respectively), showed a predominance of $\mathrm{Fe}^{2+}$ over $\mathrm{Fe}^{3+}$, which is probably - apart from relatively high share of these components - the cause of its cold, dark grey colour (Fig. 3). Mössbauer parameters of this sample spectrum indicate that the $\mathrm{Fe}^{2+}$ ion can occur in octahedral coordination, resulting - as it was previously mentioned in a greenish-blue hue. In another sample (PZ-2), the cation of $\mathrm{Fe}^{3+}$ prevails over $\mathrm{Fe}^{2+}$, while the value of the isomer shift suggests its tetrahedral coordination. The chemical analysis of this sample showed - along with the mean content of $\mathrm{Fe}_{2} \mathrm{O}_{3}(0.33 \%)$ - a relatively high share of $\mathrm{TiO}_{2}, \mathrm{Ce}$, and $\mathrm{Nd}(0.073 \%, 40$ and $24 \mathrm{ppm}$, respectively), which may account for its warm, reddish colour

PW-2

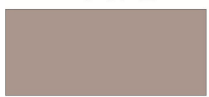

$\mathrm{PZ}-2$

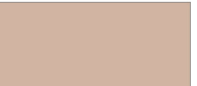

Fig. 3. Colour of the samples examined with the use of Mössbauer spectroscopy

Rys. 3. Barwy próbek poddanych badaniom metodą spektroskopii mössbauerowskiej

A chemical analysis of main and trace elements and a Mössbauer studies were both performed for the raw material samples, while the colour parameters were measured on samples fired in $1200^{\circ} \mathrm{C}$. Therefore, in the course of future examinations, the crucial issue will be the determination of phase transformations that took place in course of the thermal treatment of the samples, with special attention paid to the ferruginous phases.

The work was performed within the statutory works of MEERI of the Polish Academy of Sciences

Acknowledgement. The Author would like to thank Dr. Hab. Artur Błachowski (Pedagogical University, Kraków) for the collection of Mössbauer spectra and determination of $\mathrm{Fe}^{3+} / \mathrm{Fe}^{2+}$ ratio

\section{REFERENCES}

Alberto et al. 1992 - Alberto, H.V., Gil, J.M., Ayres DeCampos, N. and Mysen, B.O. 1992. Equilibria of iron in Ti-bearing calcium silicate quenched glasses. Journal of Non-Crystalline Solids, pp. 39-50.

Bancroft, G.M. 1973. Mössbauer Spectroscopy. Londyn: McGraw Hill.

Bolewski et al. 1991 - Bolewski, A., Budkiewicz, M. and Wyszomirski, P. 1991. Surowce ceramiczne. Warszawa: Wydawnictwa Geologiczne, 397 pp. (in Polish).

Bolewski et al. 1981 - Bolewski, A., Kubisz, J. and Żabiński, W. 1981. Mineralogia ogólna. Warszawa: Wydawnictwa Geologiczne, 434 pp. (in Polish). 
Chyandrasekhar, S. and Ramaswamy, S. 2002. Influence of mineral impurities on the properties of kaolin and its thermally treated products. Applied Clay Science 21, pp. 133-142.

Czaja, M. 2002. Luminescencja jonów chromu w naturalnych krzemianach. Katowice: Prace Naukowe Uniwersytetu Śląskiego 2058, 83 pp. (in Polish).

Dziubak, C. 2012. Fizykochemiczne podstawy syntezy ceramicznych pigmentów cyrkonowych. Ceramika/Ceramics 112, 179 pp. Wyd. PAN - Oddz. w Krakowie (in Polish)

Lewicka, E. 2013. Barwa po wypaleniu a skład mineralny kopalin skaleniowych z rejonu Sobótki. Gospodarka Surowcami Mineralnymi - Mineral Resources Management 29(1), pp. 35-51 (in Polish).

Lewicka, E. 2015. Badanie wpływu domieszek żelaza na parametry barwy kopalin skaleniowo-kwarcowych po wypaleniu. Gospodarka Surowcami Mineralnymi-Mineral Resources Management 31(1), pp. 81-94 (in Polish).

Mielicki, J. 1997. Zarys wiadomości o barwie. Łódź: Fund. Rozw. Pol. Kolor (in Polish).

Nassau, K. 1978. The origins of color in minerals. American Mineralogist 63, pp. 219-229. Mineralogical Society of America.

Sikora, W. 1974. Żelazo w kaolinach pierwotnych Dolnego Śląska. Prace Mineralogiczne 39. Warszawa: Wydawnictwa Geologiczne, 76 pp. (in Polish).

Spiering, B. and Seifert, F. A. 1985. Iron in silicate glasses of granitic composition: a Mössbauer spectroscopic study. Contributions to Mineralogy and Petrology. Springer-Verlag, pp. 63-73.

Steffen et al. 1984 - Steffen, G., Seifert, F.A. and Amthauer, G. 1984. Ferric iron in sapphire: A Mössbauer spectroscopic study. American Mineralogist 69, pp. 339-349. Mineralogical Society of America.

Weaver, C.E. 1976. The nature of $\mathrm{TiO}_{2}$ in kaolinite. Clays and Clay Minerals 24, pp. 215-218.

\title{
BADANIA GRANITOIDÓW Z REJONU SOBÓTKI \\ W ŚWIETLE TEORII POWSTAWANIA BARWY MINERAŁÓW
}

\author{
Słowa kluczowe \\ przyczyny barwy minerałów, teorie fizyki kwantowej, metale przejściowe, \\ spektroskopia mössbauerowska
}

\section{Streszczenie}

Artykuł przedstawia wyniki badań 19 próbek kopaliny skaleniowo-kwarcowej pochodzących ze złóż granitoidów z rejonu Sobótki w świetle czterech teorii fizyki, tłumaczących mechanizmy tworzenia się barw minerałów. Jest to kolejny etap prowadzonych przez autorkę badań nad przyczynami zróżnicowania zabarwienia tych próbek po wypaleniu w $1200^{\circ} \mathrm{C}$. Obejmował on wykonanie pełnej analizy chemicznej na zawartość pierwiastków głównych i śladowych wszystkich próbek oraz badania metodą spektroskopii mössbauerowskiej dwóch z nich. Analiza składu chemicznego wykazała, że najciemniejszym zabarwieniem charakteryzują się próbki o najwyższych zawartościach składników i pierwiastków barwiących: $\mathrm{Fe}_{2} \mathrm{O}_{3}, \mathrm{MnO}$, Th, U, Ce i Nd oraz V, przy relatywnie niskim udziale $\mathrm{TiO}_{2}$. Badania mössbauerowskie ujawniły przewagę ilościową $\mathrm{Fe}^{2+}$ nad $\mathrm{Fe}^{3+}$ w próbce o ciemniejszej barwie i wysokim udziale $\mathrm{Fe}_{2} \mathrm{O}_{3}$, podczas gdy parametry jej widma sugerują, że $\mathrm{Fe}^{2+}$ może zajmować pozycję oktaedryczną, co prawdopodobnie jest źródłem zimnego błękitnawego odcienia. W drugiej $\mathrm{z}$ analizowanych próbek, o niższej zawartości $\mathrm{Fe}_{2} \mathrm{O}_{3}$ i relatywnie wysokim udziale $\mathrm{TiO}_{2}, \mathrm{Ce}$ i $\mathrm{Nd}$, dominują natomiast kationy $\mathrm{Fe}^{3+}$ przypuszczalnie w koordynacji tetraedrycznej, powodując jej ciepły, czerwonawy odcień. Powyższe obserwacje i uzyskane wyniki badań skłaniają do stwierdzenia, 
że najbardziej przydatna do interpretacji barwy badanych próbek granitoidów z okolic Sobótki - na tym etapie badań - jest teoria pola krystalicznego. Wiąże ona pojawienie się określonego zabarwienia z obecnością jonów metali przejściowych, niektórych REE i aktynowców w strukturze minerałów, oraz ich zdolnością do selektywnej absorpcji światła widzialnego.

\section{THE STUDIES OF GRANITOIDS FROM THE SOBÓTKA REGION IN LIGHT OF THEORIES OF THE ORIGIN OF COLOUR IN MINERALS}

\section{Keywords}

causes of colour in minerals, quantum physics theories, transition metals,

Mössbauer spectroscopy

Abstract

The article presents the results of the studies of 19 feldspar-quartz raw materials samples, coming from deposits located in the Sobótka region, in light of four distinct physical theories explaining mechanisms for creating the colour of minerals. This is a successive stage of research carried out by the author on reasons for colour variation of samples after firing at $1200^{\circ} \mathrm{C}$. This step encompassed a detailed chemical analysis for main and trace elements contents of all the investigated samples as well as Mössbauer studies of two of them. The chemical analysis reveals that the darkest samples are characterised by the highest contents of the following colouring compounds and elements: $\mathrm{Fe}_{2} \mathrm{O}_{3}$, $\mathrm{MnO}, \mathrm{Th}, \mathrm{U}, \mathrm{Ce}, \mathrm{Nd}$, and $\mathrm{V}$, accompanied by a relatively low amount of $\mathrm{TiO}_{2}$. The Mössbauer studies demonstrated the quantitative predominance of $\mathrm{Fe}^{2+}$ over $\mathrm{Fe}^{3+}$ in the sample of a relatively darker hue with a high $\mathrm{Fe}_{2} \mathrm{O}_{3}$ content, while its spectra parameters suggest that $\mathrm{Fe}^{2+}$ is located in octahedral coordination that can result in a cold blue tint. Cations $\mathrm{Fe}^{3+}$ (located probably in the tetrahedral position) prevail in the other analysed sample that contain less $\mathrm{Fe}_{2} \mathrm{O}_{3}$ and a relatively high content of $\mathrm{TiO}_{2}, \mathrm{Ce}$, and Nd. This probably causes a warm, reddish shade of the sample. The above-mentioned observations and examinations lead to the finding that, at this stage of the investigations, the crystal field theory could be the best suited for the interpretation of colour of the studied samples. This formalism associates the colour origin with ions of the transition elements, some REE and actinides located in the structure of minerals, and their ability to selectively absorb visible light. 
